\title{
MANAJEMEN KEPALA DESA DALAM PELAKSANAAN PEMBANGUNAN Abdun, Kaja
}

Fakultas Ilmu Sosial dan Ilmu Politik Universitas Kapuas Sintang Jln. Y.C. Oevang Oeray No. 92 Sintang, Kalimantan Barat Email : kajaunka@gmail.com

\begin{abstract}
Abstrak : Kepala Desa telah melaksanakan fungsi manajemen melalui kegiatan perencanaan, pengorganisasian, pelaksanaan dan pengawasan. Perencanaan Pembangunan Infrastruktur Jalan melibatkan masyarakat, serta perangkat desa dan BPD (Badan Permusyawaratan Desa) sebagai wakil masyarakat di desa, dalam pelaksanaan kegiatan sesuai dengan kewenangan desa sedangkan dalam pelaksanaan tugas sudah dilakukan pembagian pekerjaan. Pelaksanaan Infrastruktur Jalan sesuai dengan perencanaan yang yang telah di tentukan khususnya jalan Desa, tetapi proyek jalan Kabupaten tidak sesuai dengan hasil musrenbangdes (Musyawarah Pembangunan Desa). Pengawasan kinerja Kepala Desa dilaksanakan oleh (BPD) sesuai dengan tugas dan fungsinya, namun belum maksimal karena BPD memiliki pekerjaan lain di samping sebagai BPD. Perencanaan pembangunan desa yang melibatkan masyarakat melalui musyawarah perencanaan pembangunan desa (Musrenbangdes).
\end{abstract}

Kata Kunci : Manajemen, Pembangunan

Salah satu persoalan mendasar dalam proses penyelenggaran pemerintah baik di tingkat pusat maupun daerah adalah bagaimana membangun atau menciptakan mekanisme pemerintahan yang dapat mengemban misinya untuk mewujudkan kesejahteraan masyarakat melalui pembangunan karena pemerintah juga akan membawa kemajuan bagi masyarakatnya sesuai dengan perkembangan zaman agar sejajar dengan negara-negara maju saat ini. Pemerintah perlu mengetahui apa yang dibutuhkan oleh rakyatnya serta mau mendengarkan apa kemauan masyarakatnya dan perlu melibatkan segenap kemauan dan kemampuan yang dimiliki oleh masyarakat dalam melaksanakan pembangunan. Keberhasilan pelaksanaan pembangunan masyarakat (Community development) sangat bergantung kepada peranan pemerintah dan masyarakatnya. Kedua-duanya harus mampu menciptakan sinergi, melibatkan masyarakat. Beranjak dari berbagai permasalahan tersebut maka penulis berupaya untuk menyelidiki berbagai kendala atau hambatan secara obyektif atas permasalahan yang ada melalui proses penelitian terutama perencanaan maupun pelaksanaan pembangunan desa.

Istilah manajemen, terjemahannya dalam bahasa Indonesia hingga saat ini belum ada keseragaman. Menurut Terry (dalam Manullang, 2009: 3) bahwa bila kita mempelajari literatur manajemen, maka akan ditemukan bahwa istilah manajemen mengandung tiga pengertian yaitu:"(1). Manajemen sebagai suatu proses, (2). Manajemen sebagai kolektivitas orang-orang yang melakukan aktivitas manajemen, (3) Manajemen sebagai suatu seni (Art) dan sebagai suatu ilmu pengetahuan (Science) ". Menurut Nickels, McHug and McHugh sebagaimana dikutip Mukarom (2015: 55) terdapat empat fungsi manajemen, yaitu "(1) planning (perencanaan); (2) pengorganisasian (organizing) (3) Pengimplementasian (directing) dan (4) Pengendalian (controlling)." Dalam hubungannya dengan Pemerintahan Desa, aspek organisasi akan sangat terkait dengan struktur, peran, tugas, wewenang dan tanggung jawab yang ada dalam Pemerintahan Desa. Sedangkan aspek manajemen lebih melihat proses pelayanan, penggerakan, pengawasan dan evaluasi yang ada dalam Pemerintahan Desa. Menurut Terry sebagaimana yang dikutip oleh Manullang (2009: 3) mengemukakan bahwa "Manajemen adalah pencapaian tujuan yang ditetapkan terlebih dahulu dengan mempergunakan kegiatan orang lain." Dengan demikian pelaksanaan pembangunan merupakan sebuah proses dari tindakan-tindakan : Perencanaan, Pengorganisasian, Penggiatan dan Pengawasan yang dilakukan untuk mencapai sasaran yang telah ditetapkan melalui pemanfaatan sumberdaya manusia dan sumber-sumber lainnya. Pembangunan sebagai tujuan dan cita-cita bangsa Indonesia sebagaimana yang tercantum dalam pembukaan Undang-Undang Dasar Negara Republik Indonesia tahun 1945 alenia keempat yakni "Melindungi segenap bangsa Indonesia dan seluruh tumpah darah Indonesia dan untuk memajukan kesejahteraan umum, mencerdaskan kehidupan bangsa, dan ikut melaksanakan ketertiban dunia yang berdasarkan kemerdekaan, perdamaian abadi dan keadilan sosial". Dengan demikian pelayanan publik merupakan keharusan dalam rangka melindungi dan memberikan kesejahteraan serta keadilan bagi seluruh masyarakat Indonesia.

Dengan diberlakukannnya sistem pemerintahan otonomi daerah seperti yang diatur dalam UndangUndang 23 Tahun 2014 Tentang Pemerintahan Daerah. Pemerintah Daerah diberikan kewenangan untuk mengatur dan mengurusi rumah tangga pemerintahanya sendiri, serta dapat melayani masyarakat dengan baik mengingat rentang kendali semakin sempit sehingga pelayanan yang sebaik-baiknya dapat dilaksanakan dengan menggunakan pelayanan publik yang sebaik 
mungkin. Selanjutnya menurut Keputusan MENPAN Nomor 63 Tahun 2004 menyatakan bahwa, "Hakikat pelayanan publik adalah pemberian pelayanan prima kepada masyarakat yang merupakan perwujudan kewajiban aparatur pemerintah sebagai abdi masyarakat. Menurut Ratminto dan Atik Septi Winarsih $(2015: 6)$ mengatakan bahwa,"Pelayanan publik atau pelayanan umum dapat diartikan sebagai segala bentuk jasa pelayanan, baik dalam bentuk barang publik maupun jasa publik yang pada prinsipnya menjadi tanggungjawab dan dilaksanakan oleh instansi pemerintah dipusat, di Daerah, dan dilingkungan BUMN atau BUMD dalam rangka upaya pemenuhan kebutuhan masyarakat maupun dalam rangka pelaksanaan ketentuan peraturan perundang-undangan." Sejalan dengan pendapat ahli di atas, Pemerintah perlu mengetahui apa yang dibutuhkan oleh rakyatnya serta mau mendengarkan apa kemauan masyarakatnya dan perlu melibatkan segenap kemauan dan kemampuan yang dimiliki oleh masyarakat dalam melaksanakan pembangunan.

Menurut George Terry sebagaimana dikutip oleh Syafii (2011 : 2) menjelaskan bahwa," Management is distinct process consisting of planning, organizing, actuating and controlling performed to determine and accomplish stated objectives by the use of human being and other resources." (Manajemen adalah suatu proses khusus yang terdiri dari perencanaan, pengorganisasian, pelaksanaan dan pengawasan yang dilakukan untuk menentukan serta mencapai sasaran yang telah ditentukan melalui pemanfaatan sumber daya manusia dan lainnya). Dalam mencapai sasaran yang telah ditentukan sangat diperlukan tindakan-tindakan berupa menjalankan dengan benar fungsi-fungsi manajemen antara lain: Perencanaan, pengorganisasian, pemberian perintah, dan pengawasan. Tentu dalam mengimplementasikan fungsi-fungsi ini dengan baik sangat tergantung pada kemampuan pemimpin dalam menggunakan kepemimpinannya serta memanfaatkan fasilitas yang tersedia.Konsekuensi logis dari kondisi ini adalah selain mampu memahami perkembangan dinamis yang ada ditengah masyarakat yang mampu mengenali berbagai aspirasi dan kebutuhan yang berkembang dalam masyarakat membutuhkan manajemen pemerintahan yang baik, oleh karena itu, kemampuan manajemen Pemerintahan Desa sangat menentukan hasil yang ingin di capai tetapi harus didukung oleh SDM yang memadai dengan meningkatkan pembangunan pemberdayaan masyarakat Desa, dan diperlukan kemampuan dalam mengkomunikasikan kebutuhan-kebutuhan masyarakat.

Sejalan dengan hal tersebut pelaksanaan pembangunan memang tidak dapat dilakukan secara spontanitas karena dalam proses pembangunan diperlukan perencanaan yang matang sehingga hasilnya dapat bermanfaat bagi masyarakat dan menyentuh kehidupan masyarakat secara keseluruhan, oleh karena itu, pelaksanaan pembangunan dilakukan oleh pemimpin melalui perencanaan dengan memperhatikan dukungan anggaran yang berorientasi pada kecepatan dan efesiensi ekonomis. Perencanaan memberikan kejelasan arah bagi setiap kegiatan, sehingga setiap kegiatan dapat diusahakan dan dilaksanakan seefisien dan seefektif mungkin, sebab perencanaan memudahkan dalam melakukan koordinasi di antara berbagai bagian dan memaksimalkan pekerjaan serta menghemat waktu, usaha dan dana.Perencanaan strategis Menurut Rusdiana dkk (2014 : 147) adalah, "Perencanaan jangka panjang yang dipusatkan pada organisasi secara keseluruhan sehingga manajer memandang organisasi sebagai suatu unit total dan memutuskan apa yang hendak dilakukan dalam jangka panjang untuk mencapai tujuan organisasi."Dengan demikian perencanaan yang dilakukan adalah untuk memperkirakan apa yang terjadi dimasa yang akan datang sehingga menempatkan perencanaan menjadi sangat penting dalam sebuah organisasi secara keseluruhan dimanapun organisasi itu berada baik organisasi pemerintahan maupun organisasi swasta.

Menurut Taufiq (2013 : 44) bahwa," Perencanaan adalah penentuan segala sesuatu sebelum dilakukan kegiatan-kegiatan, fungsi perencanaan manajer meliputi usaha pemilihan berbagai alternatif tujuan, strategi, kebijaksanaan, serta taktik yang akan dijalankan." Definisi ini mengandung pengertian bahwa para pemimpin mencapai suatu tujuan organisasi dengan cara mengatur orang-orang lain untuk melaksanakan apa yang perlu dalam pekerjaan itu, bukan dengan cara melaksanakan pekerjaan itu oleh dirinya sendiri, oleh karena itu, secara esensial konsep perencanaan strategik ini dapat diterapkan pula dalam konteks pelaksanaan pembangunan khususnya pada tingkat desa, dewasa ini sedang menghadapi berbagai tantangan internal maupun eksternal, sehingga membutuhkan perencanaan yang benar-benar dapat menjamin keberlangsungan pembangunan desa. Berbagai tuntutan pelayanan oleh masyarakat mengakibatkan pemerintahan khususnya di pedesaan harus semakin memahami peran, tugas dan fungsi pemerintahan yang benar. Karena proses pelayanan tidak akan berlangsung baik apabila tidak dimulai dari pemahaman atau struktur, peran, tugas, wewenang dan tanggung jawab. Dengan demikian maka menuntut kemampuan pimpinan dalam menggerakkan dan mengontrol kegiatan bawahannya. Kegiatan ini juga akan terlaksana dengan baik perlu memilih dan menghubungkan fakta dan membuat serta menggunakan asumsi mengenai masa yang akan datang dengan 
merumuskan kegiatan yang diperlukan untuk mencapai hasil yang telah ditetapkan. Sejalan dengan hal tersebut sehingga pimpinan perlu melakukan perencanaan dengan sebaik mungkin.

Menurut Atmosudirdjo (dalam Syafii, 2011: 81) Perencanaan adalah "Perhitungan dan penentuan dari apa yang akan dijalankan di dalam rangka mencapai suatu prapta (objektif) yang tertentu, dimana, bila mana, oleh siapa, dan bagaimana tata caranya." Berdasarkan pendapat ahli tersebut maka orang-orang yang dalam organisasi perlu memahami struktur, peran, tugas, wewenang dan tanggung jawab dan melaksanakan tugas sesuai dengan bidang masing-masing kapan dan dimana saja baik dalam pelaksanaan pembangunan maupun dalam memberikan pelayanan pada masyarakat dalam yang berlangsung terusmenerus. Soeharya (2009 : 56) mengatakan bahwa," Landasan hukum bidang perencanaan pembangunan baik oleh pemerintah pusat maupun pemerintah Daerah adalah Undang-Undang Nomor 25 Tahun 2004 Tentang Sistem Perencanaan Pembangunan Nasional." Dalam Undang-Undang tersebut di tetapkan bahwa system perencanaan pembangunan nasional adalah satu kesatuan tata cara perencanaan pembangunan untuk menghasilkan rencana pembangunan dalam jangka panjang, jangka menengah dan jangka pendek yang dilaksanakan oleh unsure penyelenggara pemerintahan di pusat dan di daerah dengan melibatkan masyarakat, demikian juga pelaksanaan pembangunan desa dalam peremcanaan dan pelaksanaannya memerlukan dukungan dari masyarakat secara keseluruhan.

Williams (1966) mengatakan sebagaimana yang dikutip oleh Afifuddin (2012:95) bahwa proses dari perencanaan adalah : (1) "Menentukan atau menetapkan dengan jelas maksud dan tujuan (2) Menentukan alternatif (3) Mengatur sumbersumber yang di perlukan (4) Menentukan organisasi, metode dan prosedur (5) Menentukan atau menetapkan rencana itu sendiri." Setiap organisasi dimanapun tidak dapat terlepas dari proses perencanaan dan memerlukan perencanaan dalam mencapai tujuan yang telah disetujui sebelumnya, sehingga perencanaan merupakan proses pemikiran yang matang merupakan perwujudan dari kemampuan pimpinan dalam merumuskan pencapaian tujuan. Tujuan yang ingin dicapai harus dirumuskan melalui perencanaan yang baik dan jelas sehingga arah kebijakan dalam menentukan kegiatan menjadi tolok ukur keberhasilan organisasi dalam menjalankan tugas dan fungsinya. Menurut Robbins Sebagaimana dikutip oleh Torang (2014 : 167) bahwa,"Perencanaan adalah proses pendefinisian sasaran organisasi, menetapkan strategi untuk mencapai tujuan organisasi serta menyusun keseluruhan rencana kemudian diintergrasikan dan dikoordinasikan dengan aktivitas organisasi."
Organisasi merupakan suatu sistem terbuka sehingga tidak mungkin melepaskan diri dari pengaruh lingkungan baik internal maupun eksternal tempat mereka berada. Pemerintah merupakan salah satu wujud organisasi yang bersifat dinamis. Menurut Gitosudarmo (2000:1) “organisasi adalah suatu sistem yang terdiri dari pola aktivitas kerja sama yang dilakukan secara teratur dan berulangulang oleh sekelompok untuk mencapai tujuan. “" Dalam rangka pencapaian tujuan yang dimaksud sebuah organisasi harus memikirkan agar organisasi maju dan berkembang baik dari segi pelayanan maupun pelaksanaannya dalam pembangunan, oleh karena itu pembangunan desa terus dilaksanakan untuk mencapai kesejahteraan dan kemakmuran rakyat. Dengan perumusan di atas jelas bahwa pengorganisasian merupakan langkah kearah pelaksanaan rencana yang telah disusun sebelumnya, sebab pengorganisasian merupakan fungsi organik manajemen. Hasil dari pada proses pengorganisasian adalah suatu organisasi yang dapat digerakan sebagai suatu kesatuan yang bulat dan utuh. Sejalan dengan pendapat ahli di atas berarti fungsi pengorganisasian merupakan fungsi yang sangat penting dari manajemen yang dijalankan dalam sebuah kebijakan maupun pengambilan keputusan. Setiap pemimpin dalam sebuah organisasi dimanapun dalam menjalankan fungsinya pasti mengambil keputusan baik organisasi pemerintahan maupun milik swasta, baik yang berstruktur formal maupun informal pasti mempunyai tujuan spesifik dalam sebuah keputusan dalam rangka untuk mencapai tujuan, oleh karena itu setiap organisasi dalam mencapai tujuan yang sudah di tetapkan memerlukan infut untuk menghasilkan outfut dalam arti untuk menghasilkan sesuatu yang bermanfaat dan bernilai lebih tinggi.

Pengorganisasian (organizing) adalah fungsi dari manajemen yang kedua Terry mengatakan sebagaimana yang dikutip oleh Silalahi (2002 : 170) mengemukakan bahwa: "Pengorganisasian adalah Pembagian pekerjaan yang direncanakan untuk diselesaikan oleh anggota kelompok pekerjaan, penentuan hubungan-hubungan pekerjaan di antara mereka dan pemberian lingkungan pekerjaan yang sepatutnya." Oleh karena itu, tindakan mengusahakan hubungan- yang efektif dapat bekerja sama secara efisien, dan memperoleh kepuasan pribadi dalam melaksanakan tugas tertentu guna mencapai tujuan atau sasaran tertentu.Menurut Torang (2014 : 170) Pengorganisasian adalah,"Suatu pendistribusian pekerjaan dan tugas-tugas serta mengkoordinasikannya untuk mencapai tujuan organisasi." Tindakan pengorganisasian bukanlah pekerjaan yang sekaligus selesai tetapi membutuhkan waktu dan bahkan berlangsung selama organisasi melakukan aktivitas untuk mencapai tujuan. Menurut Silalahi (2002 : 171) 
menjelaskan bahwa untuk memperoleh hasil pengorganisasian yang baik, perlu diperhatikan langkah-langka berikut : 1) Mengetahui tujuan 2) Membagi habis pekerjaan dalam unit organisasi 3) Menggolongkan kegiatan ke dalam unit yang operasional atau praktis 4) Menentukan wewenang dan tanggungjawab 5) Menentukan atau menyediakan sarana dan prasarana yang diperlukan 6) Memilih menempatkan dan menugaskan personil sesuai dengan keterampilan manejerial yang dimiliki 7) Mendelegasikan wewenang

Berdasarkan pendapat di atas, dapat dipahami bahwa pengorganisasian pada dasarnya merupakan upaya untuk melengkapi rencanarencana yang telah dibuat dengan susunan organisasi pelaksananya. Hal yang penting untuk diperhatikan dalam pengorganisasian adalah bahwa setiap kegiatan harus jelas siapa yang mengerjakan, kapan dikerjakan, dan apa targetnya. Organisasi adalah alat administrasi untuk mencapai tujuan yang telah direncanakan, untuk mencapai tujuan tersebut maka setiap organisasi harus bersesuaian dengan tujuan yang telah direncanakan dan akan dicapai dengan organisasi yang bersangkutan. Dengan demikian kegiatan organisasi sebagai proses pengelompokan orang-orang, alat-alat, tugas, tanggung jawab atau wewenang sedemikian rupa sehingga tercipta suatu organisasi yang dapat digerakan sebagai suatu kesatuan dalam rangka mencapai tujuan yang telah ditentukan. Sejalan dengan penjelasan di atas, James D. Mooney sebagaimana diktuip oleh Manullang (2009 : 59) mengatakan bahwa, "Organisasi adalah bentuk setiap perserikatan manusia untuk mencapai suatu tujuan bersama." Dengan demikian tujuan organisasi menjadi tujuan sekelompok orang yang ada dalam organisasi sehingga keberhasilan organisasi merupakan keberhasilan bersama sehingga tanggUngjawab menjalankan organisasi menjadi tanggungjawab bersama semua anggota organisasi, oleh karena itu, prinsip organisasi bertujuan agar organisasi dapat berjalan dengan baik, demikian juga Kepala Desa dan perangkatnya dalam menjalankan tugas harus ada pembagian pekerjaan, perumusan tujuan yang jelas, delegasi kewenangan, rentangan kekuasaan, tingkat-tingkat pengawasan, kesatuan perintah dan tanggungjawab serta adanya koordinasi.

Koordinasi dilakukan dalam rangka pelaksanaan tugas agar persepsi menjadi sama dan tidak ada perbedaan persepsi tentang sesuatu pekerjaan maupun tujuan, dengan demikian bahwa penempatan atau pembagian pekerjaan diberikan pada karyawan, atau perangkat yang cocok pada bidang masing-masing sesuai dengan keahlian yang bersangkutan. Zauhar (2015: 62) menjelaskan bahwa,"Setiap bentuk organisasi tersebut harus diisi dengan personel yang cocok dan memerlukan personel yang loyal, tergantung dan mempunyai kemauan yang tinggi, karena tugas dalam organisasi sangat kompleks, demikian pula halnya apabila organisasi tersebut termasuk organisasi birokratik akan memerlukan disiplin, hati-hati dan konsisten." Sejalan dengan pendapat ahli tersebut di atas, maka proses pengorganisasian meliputi perumusan tujuan, penempatan tugas pokok, perincian kegiatan, pengelompokan kegiatan dalam fungsi-fungsi, departementasi, penempatan otoritas organisasi. Sesuai dengan hal tersebut di atas, tugas dan kewajibannya pada pasal 2 dan 3 Kepala Desa mempunyai fungsi sebagai berikut: Melaksanakan tertib administrasi pemerintahan, pembangunan dan kemasyarakatan di tingkat Desa sesuai dengan aturan perundang-undangan yang berlaku, serta bertanggung jawab atas jalannya penyelenggaraan pemerintahan, pelaksanaan pembangunan dan pembinaan kemasyarakatan. Melaksanakan pembinaan terhadap organisasi kemasyarakatan yang ada di Desa dan melaksanakan koordinasi terhadap jalannya Pemerintahan Desa, pelaksanaan pembangunan dan pembinaan kemasyarakatan maupun tugas-tugas lain yang dilimpahkan kepada Pemerintahan Desa. Sebagaimana tercantum dalam Perda Nomor 2 Tahun 2001 Kepala Dusun mempunyai tugas membantu Kepala Desa menyelenggarakan Pemerintahan Desa didalam wilayah kerja sesuai peraturan yang berlaku.

Dalam mencapai hasil suatu tugas yang maksimal, maka masing-masing unit kerja suatu organisasi dalam pemerintahan harus memiliki rasa tanggung jawab untuk menyelesaikannya dengan baik. Sebagaimana tercantum dalam Perda Nomor 2 Tahun 2001 ayat (1) "setiap pimpinan unit organisasi di Pemerintahan Desa bertanggung jawab dalam memimpin, memberikan bimbingan, petunjuk-petunjuk dan mengawasi serta mengendalikan tugasnya". Sejalan dengan hal tersebut Undang-Undang Nomor 6 Tahun 2014 Tentang Desa, Pasal 26 ayat 1 dalam UndangUndang tersebut menjelaskan bahwa,"Kepala Desa bertugas menyelenggarakan Pemerintahan Desa, melaksanakan pembangunan Desa, pembinaan kemasyarakatan Desa dan Pemberdayaan masyarakat Desa." Selanjutnya Kepala Desa dalam menjalankan tugasnya di bantu oleh perangkat Desa sesuai dengan pasal 49 yang berbunyi : 1) Perangkat Desa sebagaimana dimaksud dalam pasal 48 bertugas membantu Kepala Desa dalam melaksanakan tugas dan wewenangnya. 2) Perangkat Desa sebagaimana dimaksud pada ayat (1) di angkat oleh Kepala Desa setelah dikonsultasikan dengan Camat atas nama Bupati/Wali kota. 3) Dalam melaksanakan tugas dan wewenangnya, Perangkat Desa sebagaimana dimaksud pada ayat (1) bertanggungjawab kepada Kepala Desa.Dalam melaksanakan tugastugasnya, Desa diberi kewenangan sebagaimana tercantum pada Undang-Undang Nomor 23 Tahun 
2014 Pasal 1 ayat (43) menjelaskan bahwa :Desa adalah desa dan desa adat atau yang disebut dengan nama lain, selanjutnya disebut Desa, adalah kesatuan masyarakat hukum yang memiliki batas wilayah yang berwenang untuk mengatur dan mengurus Urusan Pemerintahan, kepentingan masyarakat setempat berdasarkan prakarsa masyarakat, hak asal usul, dan/atau hak tradisional yang diakui dan dihormati dalam sistem pemerintahan Negara Kesatuan Republik Indonesia. Ini menunjukkan bahwa Desa diberi kewenangan yang cukup besar dalam mengatur rumah tangganya sendiri dengan tetap memperhatikan atauran yang ada dibawah naungan Negara Kesatuan Republik Indonesia. Dengan kewenangan-kewenangan tersebut tidaklah cukup apabila hanya sekedar diketahui tanpa mau mengolah kewenangan tersebut secara benar dan bertanggung jawab. Sebagai bagian dari perpanjangan tangan pemerintah daerah dalam mengelola potensi yang ada pada Desa, adalah Pemerintahan Desa itu sendiri.

Dengan demikian peran aktif dari Pemerintahan Desa dalam menata organisasi dan manajemen sangatlah penting guna tercapainya proses pembangunan yang lancar sesuai asas manfaat bagi masyarakat itu sendiri. Dalam Peraturan Pemerintah Nomor 43 Tahun 2014 tentang Peraturan Pelaksanaan Undang-Undang Nomor 6 Tahun 2014 tentang Desa menyebutkan bahwa kewenangan Desa meliputi: 1) Kewenangan berdasarkan hak asal usul; 2) Kewenangan lokal berskala Desa; 3) Kewenangan yang ditugaskan oleh Pemerintah, pemerintah daerah provinsi, atau pemerintah daerah kabupaten/kota; dan 3) Kewenangan lain yang ditugaskan oleh Pemerintah, pemerintah daerah provinsi, atau pemerintah daerah kabupaten/kota sesuai dengan ketentuan peraturan perundang-undangan.

Desa adalah kesatuan masyarakat hukum yang memiliki batas-batas wilayah yang berwenang untuk mengatur dan mengurus kepentingan masyarakat setempat, berdasarkan asal-usul dan adat istiadat setempat yang diakui dan dihormati dalam sistem Pemerintahan Negara Kesatuan Republik Indonesia. Selanjutnya Terry mengatakan sebagaimana yang dikutip oleh Torang (2014 :170) bahwa, Organizing is the arrangement of functions deemed necessary for attainment of the objective and is an indication of the authority and the responsibility assigned to individuals charged with the execution of the respective function. (Pengorganisasian adalah pengaturan fungsi yang dianggap perlu untuk mencapai tujuan dan merupakan indikasi dari otoritas dan tanggung jawab yang diberikan kepada individu yang dibebankan dengan pelaksanaan fungsi masing-masing). Dengan demikian dapat disimpulkan bahwa pengorganisasian adalah seluruh aktivitas manajemen yang diimplementasikan dalam bentuk pembagian tugas, kewenangan dan tanggungjawab, sebab tidak ada kewenangan yang tidak memiliki tanggungjawab, oleh karena itu pengorganisasian merupakan pengelompokan tugas dan menetapkan mekanisme kerja dalam satu kesatuan yang harmonis.Pelaksanaan adalah kemampuan untuk membentuk hubungan yang lanjut dalam rangkaian sebab akibat yang menghubungkan tindakan dengan tujuan.

Pendapat di atas menunjukkan bahwa pelaksanaan itu adalah melaksanakan suatu kebijakan atau program dimana akibat tersebut itu akan berdampak atau berpengaruh, sehingga akan membawa suatu dampak terhadap tatanan kehidupan dalam suatu masyarakat. Pelaksanaan pelayanan dan pembangunan tidak dapat terlepas dari prosedur, karena sebuah prosedur mengatur menentukan keteranturan dalam pelaksanaan sehingga diperluakan Standar Operasional Prosedur (SOP), standar yang dimaksud dalam rangka mencapai tujuan dengan menggunakan indikator yang menjadi pegangan dalam pelaksanaan tugas maupun pelaksanaan pembangunan sehingga nantinya tingkat keberhasilannya dapat diukur berdasarkan indikator tersebut, oleh karena itu SOP sangat diperlukan dalam aktivitas organisasi. Pelaksanaan pembangunan infrastruktur desa dan pembangunan lainnya juga memiliki prosedur sehingga pelaksanaannya tidak dapat dilakukan seketika melainkan memperhitungkan anggaran melalui perencanaan yang matang, dapat saja pembangunan itu dilaksanakan secara spontan tetapi akhirnya dapat mengabaikan bidang pembangunan yang lainnya sehingga Kepala Desa dalam melaksanakan pembangunan memerlukan pola-pola fungsi manajemen mulai dari perencanaan sampai pada proses evaluasi, pelaksanaan pembangunan harus didukung dengan anggaran yang memadai sehingga jika sudah dilakukan perencanaan tetapi tanpa dukungan anggaran maka pembangunan apapun tidak dapat terlaksana dengan baik sehingga akhirnya pembangunan mengalami kendala dalam pelaksanaannya. Selanjutnya dalam pelaksanaan pembangunan tentu yang ingin di capai adalah tujuan dan sasaran sesuai perencanaan, baik perencanaan jangka pendek, jangka menengah maupun jangka panjang.

Sesuai dengan hal tersebut pemerintah memberikan pedoaman atau panduan bagi seluruh instansi pemerintah pusat dan daerah dalam rangka mencapai tujuan dan sasaran sehingga diterbitkan Permenpan dan RB Nomor 35 Tahun 2012 Tentang Pedoman Penyusunan SOP Administrasi Pemerintahan. Selanjutnya harapan yang di capai melalui Permenpan dan RB Nomor 35 Tahun 2012 adalah : (1) Setiap instansi pemerintah sampai dengan unit yang terkecil memiliki SOP AP masingmasing. (2) Penyempurnaan proses 
penyelenggaraan pemerintahan (3) Ketertiban dalam penyelenggaraan pemerintahan (4) Peningkatan kualitas pelayanan kepada masyarakat. Berdasarkan Permenpan dan RB di atas, adalah pelaksanaan (actuating) pekerjaan harus memiliki SOP, hal ini tentu harus dilakukan oleh seluruh pemimpin dalam menggerakan bawahan melalui fungsi manajemen, oleh karena itu, actuating merupakan usaha menggerakkan anggota-anggota kelompok dan berusaha untuk mencapai sasaran tersebut. Dengan demikian untuk mencapai sasaran tersebut diperlukan usaha kerja nyata atau dengan istilah lain diperlukan tindakan dalam melaksanakan pekerjaan.

Actuating dimaksud agar sumber daya manusia dalam organisasi mau melakukan dan menyelesaikan pekerjaan untuk mencapai tujuan organisasi. Menurut Terry sebagaimana yang dikutip oleh Torang (2014: 173) Actuating adalah "Actuating is getting all members of the group to want to achieve the objective willingly and in keeping with the managerial planning and organizing efforts." (Menindaklanjuti adalah membuat semua anggota grup ingin mencapai tujuan dengan sukarela dan sesuai dengan perencanaan manajerial dan upaya pengorganisasian). Selanjutnya Terry menjelaskan bahwa, "actuating is to execute though others the plan." (Menggerakkan adalah untuk melaksanakan rencana meskipun orang lain).Dengan demikian berarti actuating adalah tindakan, karena sesuatu tidak akan terjadi tanpa melalui tindakan serta yakin akan mampu mengerjakan, pekerjaan tersebut memberikan manfaat bagi dirinya dan merasa dibebani oleh problem pribadi atau tugas lain yang lebih penting, atau mendesak. Robbins menjelaskan sebagaimana yang dikutip oleh Torang $(2014: 173)$ menyebutkan, "fungsi manajemen dengan istilah directing (memimpin) dalam fungsi manjemen ini pemimpin diharapkan mengarahkan dan memotivasi semua individu dalam organisasi untuk melaksanakan aktivitas untuk mencapai tujuan organisasi."

Berdasarkan pendapat ahli tersebut berarti fungsi manajemen yang ketiga actuating dapat juga di artikan sebagai pengarahan, berbentuk motivasi berupa penghargaan agar perilaku dan tindakan yang diarahkan sehingga pengarahan harus berdasarkan harapan dan hasil usaha mendatangkan kepuasan tertentu bagi orang yang di arahkan. Menurut Taufiq (2013:45) mengatakan bahwa,"Leading (pengarahan) merupakan usaha yang berhubungan dengan segala sesuatu agar semuanya itu dapat dilakukan, apa yang direncanakan dan diorganisasikan mungkin tak berjalan kecuali jika bawahan diberitahu tentang apa yang harus dilakukan."'Dengan berbagai pengarahan dan pemotivasian tujuannya agar setiap kegiatan secara optimal dilaksanakan sesuai dengan peran, tugas dan tanggung jawab masing- masing. Pelaksanaan pekerjaan merupakan suatu tindakan untuk mengusahakan agar seluruh anggota kelompok berkenan berusaha mencapai sasaran agar sesuai dengan perencanaan organisasi.

Sesuai dengan pendapat ahli di atas, Siswandi dkk (2009 : 80), "Pengarahan merupakan pelengkap bagi pedoman tertulis yang sering kali masih memerlukan penjelasan tambahan dimana jika hanya melalui pedoman tertulis saja maka anak buah tidak mudah mengerti dan memahami pedoman yang telah diterbitkan. Pengarahan sangat penting dilaksanakan dalam rangka memberikan penjelasan pada karyawan agar dapat menjalankan tugas sesuai dengan tugas pokok dan fungsinya, tugas dan fungsi yang dimaksud oleh penulis adalah tugas pokok dan fungsi aparatur desa dalam pelaksanaan pembangunan desa untuk mencapai masyarakat desa yang sejahtera dan makmur serta berkeadilan, untuk mencapai hal tersebut agar efisien dan efektif serta pencegahan adanya penyimpangan-penyimpangan maupun penyelewengan serta kekeliruan dalam pelaksanaan pembangunan desa maka diperlukan pengawasan.Pengawasan merupakan suatu kegiatan yang berusaha untuk mengendalikan agar pelaksanaan dapat berjalan sesuai dengan rencana dan memastikan apakah tujuan organisasi tercapai. Apabila terjadi penyimpangan di mana letak penyimpangan itu dan bagaimana pula tindakan mengatasinya. Selanjutnya Henry Fayol (dalam Manullang, 2009 : 173) mengatakan bahwa," Control consist in verifying whether everything occure in comformity with the plan adopted, the instruction issued and principles established. It has object to point out weaknesses and errors in order to reactivity them and prevent recurreance. It operate in everything, peoples, actions." (Pengendalian terdiri dari memverifikasi apakah segala sesuatu terjadi sesuai dengan rencana yang diadopsi, instruksi yang dikeluarkan dan prinsip-prinsip yang ditetapkan. Ini memiliki objek untuk menunjukkan kelemahan dan kesalahan untuk reaktivitas mereka dan mencegah recurreance. Ini beroperasi dalam segala hal, masyarakat, tindakan).

Dengan demikian pengawasan menurut Manullang 2009 : 174) adalah," Suatu sistem pengawasan yang efektif harus dapat segera melaporkan penyimpangan-penyimpangan sehingga berdasarkan penyimpanganpenyimpangan itu dapat diambil tindakan untuk pelaksanaan selanjutnya agar pelaksanaan selanjutnya agar pelaksanaan keseluruhan benarbenar dapat sesuai atau mendekati apa yang direncanakan sebelumnya." Fungsi-fungsi manajemen ini berjalan saling berkaitan antara fungsi yang satu dengan fungsi lainnya sehingga menghasilkan apa yang disebut dengan proses manajemen. Proses manajemen merupakan proses 
interaksi antara berbagai fungsi manajemen. Dalam perspektif pemerintahan, agar tujuan manajemen di pemerintahan Desa dapat tercapai secara efektif dan efisien, maka fungsi pengawasan harus berjalan disamping fungsi manajemen yang lainnya. Syafii (2011 : 112) mengatakan, "Pengawasan adalah salah satu fungsi dalam manajemen pemerintahan untuk menjamin agar pelaksanaan kerja pemerintah berjalan sesuai dengan standar yang telah ditetapkan dalam perencanaan pemerintahan, agar masyarakat serta warga bangsa mencapai keadaan adil makmur dalam waktu yang sudah di tentukan bersama." Pembangunan masyarakat Desa merupakan bagian yang integral dari pembangunan nasional, oleh karena itu, pembangunan desa tidak dapat diabaikan dalam pelaksanaannya sehingga memerlukan pengawasan yang baik dari semua komponen bangsa dalam rangka membeerika pelayanan pada masyarakat, sebab pemberi pelayanan pada masyarakat merupakan fungsi dari pemerintah.Rasyid (2002 : 59) mengatakan bahwa," Fungsi-fungsi pemerintahan secara umum berkenaan dengan fungsi pengaturan, pelayanan, pemberdayaan, dan pembangunan.

Pelaksanaan fungsi pengaturan yang lazim dikenal sebagai fungsi regulasi dengan segala bentuknya dimaksudkan sebagai usaha untuk menciptakan kondisi yang tepat sehingga menjadi kondusif bagi berlangsungnya berbagai aktivitas termasuk terciptanya tatanan sosial yang baik di berbagai kehidupan masyarakat."Sesuai dengan pemdapat ahli tersebut maka pelaksanaan pembangunan desa memerlukan keterlibatan masyarakat secara keseluruhan termasuk pengawasan pelaksanaannya, Pemerintah selain melaksanakan pembangunan juga menjalankan fungsi pengawasan demi menjaga tertibnya masyarakat bangsa dan Negara oleh karena itu, pemerintah adalah suatu lembaga dalam tingkat tertentu berfungsi menjaga dan menjaminsistem ketertiban sosial dalam masyarakat. Sehubungan dengan hal tersebut Rasyid sebagaimana dikutip oleh Labolo (2013 : 33) mengatakan bahwa," Tujuan utama dibentuknya pemerintahan adalah untuk menjaga suatu sistem ketertiban dimana masyarakat bisa menjalani kehidupan secara wajar." Pemerintah tanpa fungsi manajemen dalam menjalankan fungsinya tidak akan berjalan sesuai dengan yang diharapkan, karena kemampuan pemerintah dalam menjalankan tugas dan fungsinya mencerminkan kualitas pemerintahan. Dengan demikian, setiap kegiatan pemerintah Desa harus memiliki perencanaan serta pengawasan yang jelas dan realisitis, pengorganisasian yang efektif dan efisien, pengerahan dan pemotivasian seluruh aparatur Desa untuk selalu dapat meningkatkan kualitas kinerjanya, dan pengawasan secara berkelanjutan.
Menurut Syafii (2011 : 109) bahwa,"Pengawasan dapat dirumuskan sebagai proses penentuan apa yang harus dicapai yaitu standar, apa yang sedang dilakukan yaitu pelaksanaan menilai pelaksanaan, dan bila perlu melakukan perbaikan-perbaikan sehingga pelaksanaan sesuai dengan rencana, yaitu selaras dengan standar (ukuran)." Jadi pengawasan berarti melakukan perbaikanperbaikan kearah yang sewajarnya dan menghindari atau mencegah penyimpangan dari standar atau indicator yang telah di rencanakan sebelumnya, dengan kata lain bahwa penyimpangan dapat di ketahui jika tidak sesuai dengan perencanaan, disinilah pentingnya pengawasan dalam pelaksanaan kegiatan atau aktivitas baik pelayanan maupun pelaksanaan pembangunan secara menyeluruh, pembangunan desa maupun pembangunam nasional. Stephen Robein mengatakan sebagaimana yang di kutip oleh Syafii (2011:109) bahwa,"Control can be defined as the process of monitoring activities to ensure they are being accomplished as plenned and of correcting any significant devistions." (Pengawasan dapat didefinisikan sebagai proses kegiatan pemantauan untuk memastikan bahwa pekerjaan sedang diselesaikan sebagaimana ditentukan dan mengoreksi setiap pengabdian yang signifikan). Pengawasan tersebut merupakan proses pengamatan dari pada pelaksanaan seluruh kegiatan organisasi untuk menjamin agar semua pekerjaan yang dilaksanakan dapat berjalan lancar sesuai dengan rencana yang ditetapkan sebelumnya tanpa adanya penyimpangan. Sejalan dengan hal tersebut Silalahi (2002: 175) mengatakan bahwa," Kegiatan pengawasan dimaksudkan untuk mencegah penyimpangan-penyimpangan dalam pelaksanaan kegiatan atau pekerjaan dan sekaligus melakukan tindakan-tindakan perbaikan apabila penyimpangan sudah terjadi dari apa yang sudah direncanakan."

Senada dengan pendapat tersebut di atas bahwa pengawasan bertujuan agar pekerjaan terlaksana sesuai dengan rencana yang ditetapkan sebelumnya. Menurut Siagian (2015 : 175) bahwa," Pengawasan ialah proses pengamatan daripada pelaksanaan seluruh kegiatan organisasi untuk menjamin agar semua pekerjaan yang sedang dilakukan berjalan sesuai dengan rencana yang telah ditetapkan." Dari pendapat di atas dapatlah disimpulkan bahwa pengawasan adalah sebagai bagian dari aktivitas dan tanggung jawab pimpinan dengan sasaran pengawasan adalah mewujudkan dan meningkatkan efisiensi, efektivitas, rasionalitas dan ketertiban dalam pencapaian tujuan dan pelaksanaan tugas-tugas organisasi. Hasil pengawasan harus dijadikan masukan bagi pemimpin yang melaksanakan kegiatan dan 
menjalankan tugas sesuai dengan kewenangan dan tanggungjawabnya dalam mengambil keputusan. Menurut Soeharyo (2009: 74) bahwa, "Pengawasan adalah salah satu fungsi organik manajemen, yang merupakan proses kegiatan pimpinan untuk memastikan dan menjamin bahwa tujuan dan sasaran serta tugas-tugas organisasi akan dan telah terlaksana dengan baik sesuai dengan rencana, kebijakan, instruksi dan ketentuanketentuan yang telah ditetapkan.” Dengan demikian pengawasan merupakan serangkaian kegiatan pengendalian yang terus menerus dilakukan oleh pimpinan langsung terhadap bawahannya secara preventif atau refresif.

Selain pengawasan di atas, masih ada jenis pengawasan lain seperti pengawasan Legislatif (wasleg) dan pengawasan politik, pengawasan masyarakat. Tujuan dari pengawasan secara umum untuk menghindari penyimpangan-penyimpangan sehingga pelaksanaan tugas dapat efektif dan efisien sesuai dengan yang di harapkan. Menurut Iman dkk (2009 : 83) bahwa,"Controling (pengawasan) adalah memantau atau memonitor pelaksanaan rencana apakah telah dikerjakan dengan benar atau tidak atau suatu proses yang menjamin bahwa tindakan telah sesuai dengan rencana." Berdasarkan pendapat ahli tersebut pengawasan dilakukan dengan cara memonitor secara langsung kegiatan yang dilakukan bawahan apakah sudah efektif atau belum apakah ada halhal yang perlu diperbaiki atau tidak, selain itu kemungkinan terjadinya penyimpangan atau tidak berarti keberhasilan melaksanakan kegiatan sudah sesuai dengan rencana maka pelaksanaan kegiatan menjadi efektif dan efisien. Pengawasan memiliki tujuan agar kegiatan itu berjalan sesuai dengan rencana yang telah di tetapkan. Berdasarkan pendapat ahli di atas, pengawasan merupakan bentuk pengukuran terhadap kinerja seseorang dengan berdasarkan hasil yang diperoleh tanpa adanya penyimpangan sehingga pelaksanaannya menjadi efektif dan efisien sesuai dengan perencanaan yang telah di tetapkan sebelumnya. Pengawasan tidak tidak mungkin dapat dilaksanakan tanpa kegiatan perencanaan dan rencana tidak akan tercapai secara optimal jika tidak di sertai dengan pelaksanaan fungsi pengawasan.Saydam (2000:584) mengemukakan bahwa,'Pengawasan merupakan kegiatan yang dilakukan untuk mengendalikan pelaksanaan pekerjaan yang dilakukan, agar proses pekerjaan itu sesuai dengan hasil yang diinginkan." Tujuan dan sasaran organisasi tersebut tidak mungkin tercapai sekaligus, tetapi melalui pentahapan. Demikian juga pelaksanaan pembangunan tidak mungkin tercapai tujuannya dalam waktu bersamaan sehingga dalam pelaksanaan pembangunan menggunakan skala prioritas dalam arti bidang apa yang menjadi prioritas, sementara pengawasan dilakukan agar semua aktivitas dapat berjalan dengan baik tanpa adanya penyimpangan. METODE PENELITIAN

Jenis Penelitian yang digunakan adalah deskriptif. Penelitian deskriptif untuk memperoleh gambaran secara sistematik, faktual dan akurat mengenai fakta-fakta yang dilapangan, sedangkan pendekatan kualitatif adalah prosedur penelitian yang menghasilkan data deskriptif berupa kata-kata tertulis atau kesan dari orang-orang dan perilaku yang diamati. Subjek penelitian dalam penelitian ini adalah informan kunci (ke infoeman) dalam Moleong (2002:245) " yang dipilih dengan pertimbangan yang bersangkutan menguasai persoalan dan informasi yang sedang di teliti, dan mau memberikan data yang di perlukan sesuai dengan ruang lingkup penelitian". Subjek penelitian ditetapkan dengan teknik porposive sampling (sampel bertujuan) artinya hanya terbatas pada mereka yang menguasai persoalan. Informasi data dalam penelitian melalui dua sumber yakni lapangan dan dokumen, sejalan dengan hal tersebut berarti subjek penelitian merupakan sumber data.Adapun yang akan peneliti pilih sebagai subjek penelitian adalah sebagai berikut : Kepala Desa Kebiau Baru Kecamatan Sintang Kabupaten Sintang, Sekretaris Desa Kebiau Baru Kecamatan Sintang Kabupaten Sintang, Ketua Badan Permusyawaratan Desa (BPD), Kepala Dusun. Teknik pengumpulan data merupakan langkah yang paling strategis dalam penelitian, karena tujuan utama dari penelitian adalah mendapatkan data. Menurut Sugiyono (2017 : 223) Bahwa, "Dalam penelitian kualitatif instrument utamanya adalah peneliti sendiri, namun selanjutnya setelah fokus penelitian menjadi jelas,maka kemungkinan akan di kembangkan instrument sederhana yang diharapkan data dan membandingkan dengan data yang telah di temukan melalui observasi dan wawancara. Adapun teknik pengumpulan data dalam penelitian ini adalah: Wawancara adalah merupakan kegiatan pengumpulan data dengan cara bertatap muka secara langsung dengan sumber data sambil melaksanakan tanya jawab mengenai masalah yang diteliti. Menurut Danim (2002 : 130) bahwa,"Wawancara merupakan sebuah percakapan antara dua orang atau lebih pertanyaan nya diajukan oleh peneliti kepada subjek penelitian untuk di jawab.”Observasi. Menurut Hadi (dalam Sugiyono, 2017 : 145) "Observasi merupakan suatu proses yang kompleks, suatu proses yang tersusun dari pelbagai proses biologis dan psikologis dan yang paling penting dari proses tersebut adalah pengamatan dan ingatan. Observasi dalam penelitian ini diarahkan kepada pengamatan secara langsung terhadap kegiatan yang tampak dan berkaitan dengan ruang lingkup penelitian.Studi Dokumentasi. Dokumen dapat berupa arsip, foto copy, kamera. 
Menurut Bungin (2015 : 144) “Analisis data dalam penelitian berlangsung bersamaan dengan proses pengumpulan data," Setelah keseluruhan data yang diperlukan terkumpul maka pengelolaan data dalam penelitian ini menggunakan teknik analisis data kualitatif. Teknik analisis kualitatif dalam penelitian ini yaitu setelah seluruh data terkumpul baik data primer maupun data sekunder, maka data-data tersebut dituangkan dalam pernyataan-pernyataan, kalimat-kalimat atau ungkapan-ungkapan berupa naratif, yang pada akhirnya dianalisis sesuai dengan tujuan penelitian. Fungsi dari analisis data adalah memperlakukan data empiris ke dalam suatu bentuk yang dapat diinterpretasikan dan dapat pula memberikan kejelasan sebagai jawaban atas pengujian dan pemecahan masalah. Lokasi penelitian dilakukan di Desa Kebiau Baru Kecamatan Sintang Kabupaten Sintang.

\section{HASIL PENELITIAN DAN PEMBAHASAN}

Desa Kebiau Baru merupakan salah satu dari 4 Dusun yang ada di wilayah Kecamatan Sintang Kabupaten Sintang. Untuk sampai di Desa ini dapat ditempuh dari Ibu Kota Kecamatan dengan jarak $20 \mathrm{KM}$ dengan menggunakan sarana transportasi darat dan air.Desa Kebiau Baru memiliki luas wilayah yaitu sekitar $8.900 \mathrm{Ha}$. Dengan wilayah Desa yang cukup luas tercatat untuk lahan persawahan 20 ha perkebunan 7000 ha dan pemukiman penduduk sekitar 14.609 ha. Luas perkarangan 10 ha, luas pekuburan 4 ha. Luas lahan lain-lainnya 2 ha. Secara administratif, Desa Kebiau Baru terdiri dari 4 Dusun yaitu Dusun Kebiau Baru, Dusun Sungai Daun, Dusun Simpang Permai, Dusun Lubuk Kawik, dimana di dalam wilayah keempat Dusun tersebut terdapat 4 RW dan 4 RT. Desa Kebiau Baru telah memiliki batasbatas wilayah yang jelas sebagai berikut:Sebelah Timur berbatasan dengan Kelurahan Akcaya I, Sebelah Barat berbatasan dengan Desa Empaka Kebiau Raya, Sebelah Selatan berbatasan dengan Desa Jerora I, Sebelah Utara berbatasan dengan Desa Ampar Bedang. Desa Kebiau Baru merupakan bagian integral dari wilayah administratif Kabupaten Sintang termasuk iklim tropis dengan dua musim, yaitu musim penghujan dan musim kemarau. Hal ini disebabkan letak wilayah Kabupaten Sintang yang termasuk dalam Propinsi Kalimantan Barat yang tepat dilalui oleh garis khatulistiwa. Penduduk Kebiau Baru hidup harmonis karena tidak membeda-badakan suku dan agama. Selanjutnya mata pencaharian masyarakat Desa Kebiau Baru sangat bervariasi dan penduduk Desa Kebiau Baru sebagian besar sebagai petani sebanyak 235 jiwa, sedangkan penduduk yang berwirausaha sebanyak 101 orang bekerja pada perusahaan dan tambang emas, selain itu sebagai tukang berjumlah 10 jiwa, dan sebagai pedagang sebanyak 8 jiwa, sementara sebagai guru kontrak dengan jumlah 3 jiwa. Dengan bermacam-macam pekerjaan yang dilakukan penduduk di desa Kebiau Baru itu menunjukan bahwa desa tersebut tidak hanya mengandalkan salah satu pekerjaan saja yaitu sebagai petani tetapi masih terdapat pekerjaan lain yang dapat menunjang perekonomian keluarga, selain mata pencaharian yang berbeda-beda tersebut penduduk juga beraneka ragam suku maupun agama. Suku bangsa yang paling dominan di Desa Kebiau Baru adalah suku bangsa Dayak yang berjumlah 369 jiwa sedangkan melayu berjumlah 72 jiwa. Sedangkan suku Jawa berjumlah 113 orang, penduduk suku Jawa terbanyak setelah suku Dayak sebab desa ini berada di sekitar perkebunan kelapa sawit dan lokasi transmigrasi sehingga pekerja paling banyak di perusahaan adalah suku Jawa, hal ini bukan di sebabkan bahwa suku lain tidak mau bekerja di perusahaan, karena penduduk yang berasal dari Kalimantan masih banyak pilihan pekerjaan dibandingkan bekerja pada perusahaan.

Selanjutnya bahwa penduduk setempat memiliki lahan untuk berkebun maupun sebagai petani sehingga lebih mudah bekerja mengolah kebun sendiri, selain penduduk Jawa ada juga penduduk bangsa atau suku lain yaitu suku Timor berjumlah 10 orang yang berdomisili di desa Kebiau Baru. Berdasarkan hal tersebut bahwa penduduk Desa Kebiau Baru merupakan penduduk yang beraneka ragam suku, agama serta tradisi yang berbeda, namun penduduk Desa tersebut rukun dan saling menghargai satu dengan yang lainnya. Demikian juga tingkat pendidikan juga bervariasi dan ratarata pendidikan penduduk Kebiau Baru adalah SMP dan SMA sedangkan pendidikan penduduk DI-DIII hanya 3 orang jika dipersentase sekitar $0,52 \%$ dari jumlah penduduk, demikian juga yang berpendidikan Strata (S1) berjumlah 7 orang atau sekitar 1,23\%. Desa Kebiau Baru berjumlah 567 jiwa, tamat SD laki-laki berjumlah 56 orang sementara 56 orang juga pernah SD tetapi tidak tamat. Dengan demikian maka di Desa Kebiau Baru penduduk yang mengenyam pendidikan SD sebanyak 112 orang laki-laki, sedangkan perempuan yang tamat SD berjumlah 34 orang sementara yang pernah Sekolah Dasar dan tidak tamat berjumlah 24 orang.

Demikian juga penduduk yang tamat SMP berjumlah 20 orang laki-laki sedangkan yang tidak tamat SMP tetapi pernah Sekolah Menengah Pertama 27 orang, jadi total penduduk yang berpendidikan SMP berjumlah 47 orang laki-laki sementara perempuan 19 orang tamat SMP sementara yang tidak tamat SMP berjumlah 23 orang. Selanjutnya tamatan SMA laki-laki berjumlah 17 orang sedangkan yang tidak tamat SMA berjumlah 34 orang dalam arti pernah sekolah di SMA. Jadi total laki-laki yang pernah mengenyam pendidikan SMA 51 orang. Selanjutnya perempuan yang tamat SMA berjumlah 21 orang tidak tamat SMA berjumlah 26 orang, jadi dapat disimpulkan bahwa perempuan 
yang pernah mengenyam pedidikan di SMA berjumlah 47 orang. Sementara penduduk yang sedang sekolah baik TK,SD,SMP sampai pada Perguruan Tinggi tidak tercantum dalam tabel di atas.

Selanjutnya penduduk Desa Kebiau baru yang menyelesaikan pendidikan DIII berjumlah 3 orang sedangkan penduduk yang berpendidikan S1 berjumlah 7 orang. Berdasarkan data tersebut masih banyak penduduk yang tidak tamat SMP maupun SMA hal tersebut menunjukan bahwa penduduk Desa Kebiau Baru yang tidak tamat pendidikan formal. Berdasarkan tabel tersebut bahwa pendidikan khsusnya di Desa Kebiau masih perlu perhatian dari pemerintah terkait, selain itu masih terdapat anak putus sekolah pada pendidikan dasar, oleh karena itu, Kepala Desa sebagai pimpinan wilayah desa diharapkan memberikan penyuluhan atau pengarahan berkaitan dengan pentingnya pendidikan dalam meningkatkan keterampilan dan pengetahuan serta meningkatkan SDM yang berkualitas. Pendidikan Aparatur Desa Kebiau Baru Kecamatan Sintang Kabupaten Sintang rata-rata tamat SMA, sehingga Aparatur Desa harus mengikuti pelatihan-pelatihan yang di adakan oleh Pemeritah Daerah dalam rangka meningkat keterampilan maupun pendidikannya. Sejalan dengan hal tersebut bahwa pendidikan memegang peranan yang sangat penting, sebab faktor sumber daya manusia beriringan dengan skill yang dimiliki oleh seorang pemimpin sehingga dapat menjadi penentu keberhasilan sebuah organisasi.

Organisasi akan berjalan dengan baik harus di dukung oleh kemampuan menggerakan serta membina bawahannya, terutama perangkat desa dan masyarakat,serta mampu membangkitkan motivasi masyarakat untuk ikut serta dalam pelaksanaan pembangunan desa. Selanjutnya bahwa dalam menampung aspirasi masyarakat desa maka keberadaan Badan Permusyawaratan Desa sangat penting sebagai wakil masyarakat di tingkat desa, sebab lembaga ini selain menampung aspirasi masyarakat juga melakukan pengawasan atas kinerja Kepala Desa, dan merancang peraturan desa namun seringkali lembaga tersebut hanya sebagai pelengkap struktur organisasi, bahkan tidak terlibat dalam proses perencanaan pembangunan. Badan Permusyawaratan Desa (BPD) mempunyai hak antara lain meminta keterangan kepada Pemerintah Desa; menyatakan pendapat; mengajukan rancangan Peraturan Desa; mengajukan pertanyaan; menyampaikan usul dan pendapat; memilih dan dipilih; dan memperoleh tunjangan. Tugas, Wewenang dan Fungsi BPD dalam penyelenggaraan pemilihan Kepala Desa adalah : (1) memberitahukan kepada kepala desa mengenai akan berakhirnya masa jabatan kepala desa secara tertulis 6 (enam) bulan sebelum berakhir masa jabatan. (2) Memproses pemilihan kepala desa paling lama 4 (empat) bulan sebelum berakhirnya masa jabatan Kepala Desa.Dalam melaksanakan tugas dan kewajibannya Kepala Desa dibantu oleh Perangkat Desa, yang terdiri dari unsur staf, unsur pelaksana dan unsur wilayah, dan Sekreataris Desa yang dipimpin oleh Sekretaris Desa. Koordinasi kegiatan, administrasi Desa, penyusunan program kerja dan lainnya yang berkenaan dengan aktivitas Pemerintahan Desa menjadi bagian dari tanggung jawab Sekretaris Desa sebagai unsur pelaksana. Namun demikian bukan berarti beban Kepala Desa menjadi ringan, dan beban Sekretaris Desa menjadi lebih berat, tetapi Sekretaris Desa juga dibantu oleh Kepala Urusan. Kepala Urusan dalam Pemerintahan Desa terbagi atas Unsur Pemerintahan, Urusan Pembangunan, Urusan Kesejahteraan Rakyat, Urusan Keuangan dan Urusan Umum, dan masingmasing Kepala Urusan bertanggung jawab langsung kepada Sekretaris Desa.

Selain Sekretaris Desa sebagai unsur yang membantu tugas Kepala Desa dalam menyelenggarakan Pemerintahan Desa, Kepala Desa juga dibantu oleh Kepala Dusun sebagai unsur pelaksana Pemerintahan Desa dengan wilayah kerja tertentu yang berada dibawah dan bertanggung jawab kepada Kepala Desa. Kepala Dusun mempunyai tugas membantu Kepala Desa menyelenggarakan Pemerintahan Desa didalam wilayah kerja sesuai peraturan yang berlaku. Sekretaris Desa mempunyai tugas membantu Kepala Desa dalam pembinaan dan pelaksanaan di bidang administrasi pemerintahan, pelaksanaan pembangunan dan pembinaan kemasyarakatan serta membantu pelayanan ketatausahaan kepada Kepala Desa. Ini menunjukkan bahwa Desa diberi kewenangan yang cukup besar dalam mengatur rumah tangganya sendiri dengan tetap memperhatikan atauran yang ada dibawah naungan Negara Kesatuan Republik Indonesia.

Dengan kewenangan-kewenangan tersebut tidaklah cukup apabila hanya sekedar diketahui tanpa mau mengolah kewenangan tersebut secara benar dan bertanggung jawab. Sebagai bagian dari perpanjangan tangan pemerintah daerah dalam mengelola potensi yang ada pada Desa, adalah Pemerintahan Desa itu sendiri. Oleh karena itu peran aktif dari Pemerintahan Desa dalam menata organisasi dan manajemen sangatlah penting guna tercapainya proses pembangunan yang lancar sesuai asas manfaat bagi masyarakat itu sendiri.Perencanaan pembangunan infrastruktur khususnya di pedesaan harus dilakukan sebaikbaiknya, melalui musyawarah desa (musrenbangdes) sebab perencanaan yang baik memudahkan pelaksanaannya, dengan demikian Kepala Desa sebagai unsur pelaksana pembangunan berupaya menggerakan masyarakat untuk terlibat dalam proses pembangunan sejak perencanaan sampai pengawasan hasil pembangunan, partisipasi masyarakat menjadi 
modal dominan bagi pelaksana pembangunan desa, sebab pembangunan desa modal dasarnya adalah swadaya gotong-royong masyarakat selaku warga yang mengetahui kebutuhan masyarakatnya sendiri.

Fungsi perencanaan dalam kegiatan pembangunan infrastruktur khususnya melibatkan masyarakat dalam perencanaan karena tanpa dukungan masyarakat pembangunan tersebut tidak dapat berhasil sesuai dengan harapan, apalagi pembangunan infrastruktur merupakan kebutuhan mandasar masyarakat, oleh karena itu, kegagalan melaksanakan pembangunan sangat merugikan semua pihak. Dengan demikian semua warga melibatkan diri dan terlibat dalam perencanaan sejak perumusan awal pembangunan ditetapkan, pembangunan desa yang dilakukan tersebut masyarakat tidak pernah terlibat dalam perencanaan maupun dalam pembahasan penggunaan anggaran sehingga kecendrungan pembangunan hanya berdasarkan usulan Kepala Desa dan perangkatnya, masyarakat tidak mengetahui pembangunan yang jadi prioritas termasuk proses perencanaan. Dalam pelaksanaan perencanaan dilakukan Kepala Desa bersama anggota BPD membahas tentang usulan pembangunan sesuai dengan kepentingan masyarakat. Perencanaan pembangunan dilakukan musyawarah bersama dengan Kepala Desa, sedangkan masyarakat jarang dilibatkan mengingat BPD adalah perwakilan masyarakat ditingkat desa, sehingga BPD di anggap sudah mewakili keseluruhan masyarakat dalam perencanaan pembangunan, dengan demikian bahwa musyawarah perencanaan pembangunan desa dilakukan oleh perangkat desa dan BPD. Sejalan dengan hal tersebut sehingga peran serta masyarakat menjadi berkurang sebab tidak ada keterlibatannya dalam proses perencanaan maupun dalam perumusan perencanaan sementara modal dasar dalam pelaksanaan pembangunan desa adalah gotong-royong artinya bahwa pembangunan desa tidak terlepas dari partisipasi seluruh lapisan masyarakat, masyarakat harus bertanggung jawab atas terselenggaranya pembangunan desa sebab masyarakat yang memiliki pembangunan dan untuk kepentingan masyarakat desa itu sendiri. Pembangunan tidak akan berjalan dengan baik bila tidak melibatkan seluruh lapisan masyarakat mengingat masyarakat sebagai objek dan subjek pembangunan desa, oleh karena itu peran serta masyarakat sangat dibutuhkan dalam pelaksanaan pembangunan melalui berbagai upaya bimbingan pengarahan kepala desa dalam pelaksanaan pembangunan maupun dalam meningkatkan kesejahteraan masyarakat. Pemberdayaan terhadap masyarakat sangat penting sehingga dapat membantu dan menolong dirinya sendiri melalui peningkatan pemberdayaan keterampilan pendampingan dari Kepala Desa.
Perencanaan merupakan langkah kegiatan untuk menetapkan tujuan yang akan dicapai beserta cara-cara untuk mencapai tujuan tersebut. Dengan demikian berarti bahwa perencanaan dilaksanakan sehubungan dengan penetapan tujuan yang ingin dicapai oleh pemerintah desa dalam meningkatkan kesejahteraan masyarakat, itulah sebabnya pembangunan harus di rencanakan dengan matang dan melibatkan semua unsur masyarakat untuk berpartisipasi dalam perencanaan maupun proses pembangunan sampai pemeliharaan hasil pembangunan bahkan menikmati hasil pembangunan masyarakat harus dilibatkan. Keberhasilan pembangunan tidak dapat dilakukan hanya secara individu tetapi harus berkelompok dan bekerja sama untuk mencapai tujuan, hal ini sebagai strategi, kebijaksanaan, program, yang dibutuhkan untuk mencapai tujuan. Dilain pihak perencanaan dapat memberikan kejelasan arah bagi setiap kegiatan pemerintahan Desa, sehingga setiap kegiatan dapat diusahakan dan dilaksanakan seefisien dan seefektif mungkin. Perencanaan membantu ketepatan untuk menyesuaikan diri dengan perubahan-perubahan lingkungan, membantu dalam kristalisasi persesuaian pada masalah-masalah utama, memungkinkan manajer memahami keseluruhan gambaran, membantu penempatan tanggung jawab lebih tepat, memberikan cara pemberian perintah untuk beroperasi memudahkan dalam melakukan koordinasi di antara berbagai bagian organisasi, membuat tujuan lebih khusus, terperinci dan lebih mudah dipahami; meminimumkan pekerjaan yang tidak pasti; dan menghemat waktu, usaha dan dana.

Pelaksanaan pembangunan sejak perencanaan sampai pelaksanaannya dibahas bersama dengan anggota BPD dalam arti bahwa aktivitas pelaksanaan kegiatan melibatkan BPD hanya saja kadang-kadang anggota BPD jarang lengkap sehingga yang sering hadir dalam pembahasan tersebut bersama Kepala Desa hanya Ketua BPD, seperti yang telah dijelaskan dalam perencanaan pembangunan anggota BPD tidak sempat hadir semua anggota karena kesibukan sebagai petani, namun demikian keputusan dapat dilaksanakan sehingga perencanaan dapat di ajukan menjadi musyawarah rencana pembangunan desa (Musrenbangdes) dan di bahas selanjutnya ditingkat Kecamatan dengan demikian, bahwa perencanaan pembangunan desa yang diajukan ditetapkan menjadi rencana pembangunan desa. Berdasarkan hal tersebut di atas, secara organisasi maka dalam pengajuan perencanaan pembangunan Kepala Desa selaku pimpinan wilayah ditingkat desa berkoordinasi dengan pemerintah Kecamatan, sebab perencanaan sampai pelaksanaan pembangunan dibahas ditingkat Kecamatan, sedangkan hasil musrenbangdes dilaksanakan ditingkat desa sebagai dasar pelaksanaan pembangunan desa. Sejalan dengan hal tersebut 
maka pelaksanaan pembangunan desa dilakukan koordinasi dengan berbagai pihak termasuk BPD tujuannya adalah agar pembangunan dilaksanakan di desa dapat diketahui oleh masyarakat desa.

Pelaksanaan pembangunan desa kadangkadang tidak sesuai dengan perencanaan yang telah di ajukan sehingga kebutuhan infrastruktur yang mendasar tidak dapat dilaksanakan sepenuhnya karena sumber pembiayaannya di danai melalui alokasi dana desa, sementara ADD dimaksud tidak dapat digunakan secara keseluruhan sebab digunakan untuk pembiayaan operasional desa dalam arti bahwa alokasi dana desa tidak dapat digunakan untuk pelaksanaan pembangunan secara keseluruhan karena bidang lain juga perlu anggaran seperti pelaksanaan pemerintahan desa dalam memberikan pelayaanan pada masyarakat terutama berkaitan dengan alat tulis kantor (ATK) dan lain-lain. Selain hal tersebut bahwa penggunaan alokasi dana desa penggunaannya sudah di atur berdasarkan petunjuk teknis maupun petunjuk pelaksanaannya sehingga penggunaan anggaran pembangunan desa dapat terlaksana dengan baik. Dengan demikian, penggunaan anggaran di sesuai dengan ketentuan yang sudah diatur berdasarkan Undang-Undang maupun ketentuan yang berlaku, oleh karena itu semakin pelaksanaan penggunaan anggaran itu sesuai dengan ketentuan maka penyimpangan penggunaan anggaran dapat diminimalisir. Sejalan dengan hal tersebut bahwa kinerja Kepala Desa dalam pelaksanaan pembangunan maupun daam memberikan pelayanan pada masyarakat di awasi oleh BPD sebagai lembaga perwakilan di tingkat desa. Dengan demikian, penggunaan anggaran dan pelaksanaan pembangunan juga tidak luput dari pengawasan BPD sementara alokasi dana desa yang bersumber dari APBN dilakukan juga oleh Badan Pengawas Daerah (Bawasda) oleh karena itu penggunaan anggaran diawasi secara internal dan eksternal.

Berdasarkan hal tersebut sehingga tidak ada waktu yang disediakan untuk memberikan pendapat, saran dan masukan dari masyarakat mengenai pembangunan desa namun disisi lain bahwa koordinasi aparatur desa, BPD dan Kepala Dusun dapat dilaksanakan walaupun tidak semua aktif sesuai dengan yang diharapkan, tetapi paling tidak ini membuktikan bahwa koordinasi sudah berjalan khusus di internal pengurus desa. Selanjutnya bahwa koordinasi wajib dilakukan bukan hanya internal aparatur desa tetapi perlu juga dilakukan dengan Perusahaan yang ada di sekitar desa maupun koordinasi dengan masyarakat dalam rangka menampung aspirasi masyarakat. Selain itu bahwa dukungan masyarakat juga sangat diperlukan dalam pelaksanaan pembangunan desa, sebab pembangunan desa dapat terlaksana dengan baik jika melibatkan seluruh masyarakat dalam arti bahwa partisipasi masyarakat sangat diharapkan sebagai modal dasar pelaksanaan pembangunan. Dengan demikian keikutsertaan masyarakat juga turut menentukan keberhasilan pembangunan ditingkat desa, oleh karena itu, dukungan masyarakat sangat diperlukan mulai dari perencanaan sampai pelaksanaan pembangunan bahkan dituntut untuk ikut andil dalam pemeliharaan hasil-hasil pembangunan. Namun demikian tidak semua masyarakat Desa dapat aktif berpartisipasi dalam memelihara hasil pembangunan karna masing-masing individu lebih mengutamakan pekerjaan sebagai petani sementara tugas sebagai pengurus desa hanya menjadi pekerjaan tambahan saja, alasannya kebutuhan ekonomi sedangkan tunjangan menjadi pengurus desa tidak dapat mencukupi keperluan sehari-hari Kepala Desa memahami kondisi yang demikian sehingga untuk melibatkan masyarakat juga menjadi sulit, hal inilah yang menjadi alasan sulitnya melibatkan semua masyarakat secara rutin sehingga keterlibatan masyarakat pada saat melakukan pekerjaan secara gotong-royong terutama dalam pembuatan jalan desa agar dapat terhubung dengan dusun di sekitar Desa pengembangan yaitu Desa Kebiau Baru.Pelakasanaan pekerjaan di dasarkan pada pembagian tugas pokok dan fungsi Pemerintah Desa hal ini tergambar dalam struktur organisasi, namun demikian sebuah struktur organisasi tidak ada artinya jika setiap personel tidak mengerti dalam melaksanakan pekerjaan yang telah di tentukan, oleh karena itu, pelaksanaan tugas memang berdasarkan pembagian pekerjaan sehingga individu yang bersangkutan dapat memahaminya dengan baik sehingga pekerjaan tidak tumpang tindih, dengan demikian, dalam pelaksanaan pekerjaan diperlukan koordinasi agar pekerjaan organisasi dapat berjalan sebagaimana yang diharapkan. Selanjutnya bahwa koordinasi dalam organisasi mutlak diperlukan dalam menjalankan kegiatan organisasi sebab tanpa dukungan dengan koordinasi dapat saja individu atau personel bekerja berjalan masing-masing akhirnya tidak dapat menjawab kebutuhan organisasi sehingga pekerjaan dalam sebuah organisasi mendapat hambatan.

Pembangunan infrastruktur di desa sangat penting karena dapat menghubungkan desa pengembangan dengan Dusun di Desa yang bersangkutan, melalui transfortasi yang lancar dapat menumbuhkan perekonomian masyarakat sebab masyarakat dapat menjual hasil pertanian ke kota, selain itu kebaradaan infrastruktur jalan yang baik dapat menghemat biaya trasfortasi dan tidak menggunakan waktu lama untuk mencapai tujuan, dengan demikian sarana dan prasarana transfortasi menjadi kebutuhan yang mendasar bagi masyarakat, oleh karena itu perhatian semua pihak terutama aparat terkait sangat diharapkan. Pembangunan infrastruktur jalan bagi masyarakat desa bertujuan memberikan kemudahan bagi warga masyarakat untuk dapat memasarkan dan 
membawa hasil pertanian untuk dijual di kota terutama di ibu kota kecamatan maupun langsung menuju ibu kota kabupaten, alasannya pembeli di kota lebih banyak di bandingkan dengan pedesaan. Dengan demikian bahwa pembangunan yang dilaksanakan di pedesaan harus dapat menjawab kebutuhan masyarakat sehingga hasilnya dapat dirasakan manfaatnya bagi masyarakat. Sejalan dengan hal tersebut di atas, Kepala Desa sebagai pemimpin dalam masyarakat, tugasnya melaksanakan pembangunan yang berorientasi pada kebutuhan masyarakat serta membawa kemajuan bagi masyarakat desa.

Hal ini penting diperhatikan dalam pelaksanaan pembangunan khususnya masyarakat desa agar terlibat dan termotivasi untuk mengerjakan secara bersama-sama baik infrastruktur jalan maupun infrastruktur lainnya sehingga memberikan dampak positif untuk masyarakat desa itu sendiri. Usaha menggerakkan anggota-anggota masyarakat dalam proses pembangunan sangat penting sebagai daya dan upaya menjadikan perencanaan menjadi kenyataan, dengan melalui berbagai pengarahan dan pemotivasian seluruh masyarakat dapat melaksanakan kegiatan secara optimal sesuai dengan peran, tugas dan tanggung jawab masingmasing sebagai warga masyarakat. Keterlibatan masyarakat sangat diperlukan bukan hanya dalam pelaksanaan pembangunan tetapi sejak perencanaan pembangunan dimulai, namun demikian menurut Kepala Dusun masih banyak masyarakat yang tidak terlibat dalam perencanaan pembangunan desa, hal ini disebabkan masyarakat memiliki kesibukan sebagai petani sehingga tidak terlibat dalam merumuskan pembangunan desa, selain itu juga dalam perencanaan pembangunan Kepala Desa tidak melibatkan masyarakat hanya melibatkan BPD dan Kepala Dusun. Dengan demikian sehingga masyarakat tidak mengetahui pembangunan yang menjadi prioritas di desanya. Sejalan dengan hal tersebut bahwa dalam pelaksanaan pembangunan desa Kepala Desa harus mampu meningkatkan peran serta masyarakat sebagai subjek dan objek pembangunan agar masyarakat bertanggungjawab serta termotivasi untuk mengerjakan pembangunan baik secara gotong-royong maupun ikut membahas pembangunan sejak perencanaan sampai pada pelaksanaan pembangunan desa.

Pengawasan sangat penting sekali dalam rangka pelaksanaan pembangunan secara efektif dan efisien sehingga anggaran yang tersedia dapat digunakan dengan baik tanpa adanya pemborosan dan penyimpangan dalam menggunakan anggaran yang pada akhirnya dalam pelaksanaan menjadi tepat guna atau tepat sasaran. Pengawasan bukan untuk mencari kesalahan serta kekeliruan seorang aparat pelaksana tetapi lebih kepada pencegahan kekeliruan pengguna anggaran agar semua kegiatan dapat berjalan dengan baik dengan dukungan dana yang telah di sediakan, walaupun dana tersebut sangat minim tetapi dengan ketepatan penggunaannya maka semuanya akan menghasilkan segala sesuatu yang bermanfaat bagi masyarakat, selain itu masyarakat juga merasakan dampak positifnya pembangunan yang dilaksanakan yang pada gilirannya masyarakat juga merasa bertanggungjawab dan ikut serta dalam memelihara pembangunan. Pengawasan BPD mengenai kinerja Kepala Desa dilaksanakan secara langsung dan tidak langsung hal ini lakukan BPD sesuai dengan bidang tugasnya dalam mengawasi pelaksanaan kegiatan pembangunan maupun pelayanan terhadap masyarakat dan ingin memastikan bentuk pelayanan pada masyarakat terlaksana dengan baik atau tidak sesuai dengan ketentuan yang berlaku. Kepala Desa menjelaskan bahwa pengawasan yang dilakukan itu sangat baik sebagai media kontrol terhadap tugas dan kewenangannya sehingga mengingatkan bahwa dalam pelaksanaan kebijakan maupun penggunaan anggaran terdapat batas-batas tertentu yang dilakukan Kepala Desa, dengan demikian membantu Kepala Desa untuk memahami peraturan maupun ketentuan atau standar yang telah ditetapkan sebelumnya, menentukan dan mengukur penyimpangan-penyimpangan, serta mengambil tindakan koreksi yang diperlukan untuk menjamin bahwa semua sumber daya manusia maupun sumber daya alam di desa dapat digunakan dengan sebaik-baiknya sehingga pelaksanaan tugas dapat efektif dan efisien dalam pencapaian tujuan. Fungsi pengawasan telah dilakukan secara baik untuk melihat pelaksanaan manajemen pemertintahan Desa, berkaitan dengan pelaksanaan pembangunan maupun kebijakan Kepala Desa, BPD juga menyadari bahwa pelaksanaan pengawasan yang dilakukan tidak dapat dilaksanakan sepenuhnya mengingat keterbatasan waktu yang digunakan karena pekerjaan anggota BPD tidak fokus hanya pada pengawasan tetapi memiliki pekerjaan pokok diluar sebagai BPD, namun demikian pelaksanaan pengawasan yang dilakukan secara tidak langsung tetap ada dengan adanya laporan Kepala Desa tentang pelaksanaan pembangunan maupun kebijakan-kebijakan yang dilakukan Kepala Desa.

Sejalan dengan hal tersebut BPD juga mengetahui tentang perkembangan aktivitas Kepala desa dalam menjalankan fungsinya sebagai pemimpin di desa walaupun pengawasannya tidak rutin dan tidak selalu anggota BPD bersama-sama dalam melakukan pengawasan, tetapi dalam membahas hal-hal yang di anggap penting Kepala Desa bersama BPD melakukan pembahasan bersama, oleh karena itu kesalahan dan kekeliruan dapat dicegah sehingga tidak terjadi penyimpangan dan kekeliruan, selain itu bahwa semua kegiatan Kepala Desa sudah ada standar dan sistem manajemen yang baku dan menjadi pola tetap 
dalam pelaksanaan kegiatan secara sistematik untuk menetapkan pelaksanaan dan perencanaan. Dengan demikian, apabila terjadi kekeliruan kebijakan atau keputusan dapat terlihat dengan jelas itu sebabnya pemerintah saat ini tidak kuatir mengeluarkan dana untuk pembangunan desa karena sistemnya sudah terpola dengan baik. Namun demikian, masyarakat tetap saja harus mengawasi aktivitas Kepala Desa dalam menggunakan anggaran yang dikeluarkan oleh pemerintah, sebab peran pengawasan bukan hanya tugas dan kewenangan BPD tetapi mengharapkan adanya keterlibatan secara aktif masyarakat secara keseluruhan, sebagai warga Negara, sebab anggaran pembangunan bukan membangun individu tertentu tetapi juga untuk seluruh masyarakat. Sejalan dengan hal tersebut di atas, tindakan koreksi yang diperlukan untuk menjamin bahwa semua sumber daya yang tersedia dipergunakan dengan cara efektif dan efisien dalam pencapaian tujuan bersama.

\section{KESIMPULAN DAN SARAN}

Perencanaan Pembangunan Infrastruktur Jalan di Desa Kebiau Baru dilaksanakan sesuai dengan musyawarah perencanaan pembangunan desa (Musrenbangdes) melibatkan masyarakat, serta perangkat desa dan BPD (Badan Permusyawaratan Desa) sebagai wakil masyarakat di desa. Pengorganisasian Pembangunan Infrastruktur Jalan dalam pelaksanaan kegiatan sesuai dengan kewenangan desa sedangkan dalam pelaksanaan tugas sudah dilakukan pembagian pekerjaan. Pelaksanaan Pembangunan Infrastruktur Jalan sesuai dengan perencanaan yang yang telah di tentukan khususnya jalan Desa, tetapi proyek jalan Kabupaten yang ada di Desa tidak sesuai dengan hasil musrenbandes (Musyawarah Pemabangunan Desa). Pengawasan Pembangunan Infrastruktur Jalan Desa dilaksanakan oleh Badan Permusyawaratan Desa (BPD) sesuai dengan tugas dan fungsinya mengawasi kinerja Kepala Desa, namun belum maksimal karena BPD memiliki pekerjaan lain di samping sebagai BPD. Adapun saran yang dapat di ajukan adalah Perencanaan pembangunan desa yang melibatkan masyarakat sebagai modal dasar pembangunan desa dilaksanakan sesuai dengan musyawarah perencanaan pembangunan desa (Musrenbangdes) perlu dipertahankan dan tingkatkan. Pengorganisasian Pemerintahan Desa dalam Pembangunan sudah dilaksanakan pembagian pekerjaan, namun demikian hendaknya Kepala Desa memberikan bimbingan dan arahan pada perangkat desa. Pelaksanaan pembangunan diharapkan sesuai dengan hasil musre bangdes ditingkat desa baik jalan desa maupun jalan Kabupaten sehingga sesuai dengan kebutuhan masyarakat. Pengawasan dilakukan oleh BPD diharapkan perlu di tingkatkan sesuai dengan tugas pokok dan fungsinya serta menjadi tanggungjawab sebagai wakil masyarakat di tingkat desa.

\section{DAFTAR PUSTAKA}

Bungin, Burhan. 2015. Metodologi Penelitian Kuailitatif, Aktualisasi Metodologis kea rah Ragam Varian Kontemporer. Jakarta : RajaGrafindo Persada

Danim, Sudarwan. 2002. Menjadi Peneliti Kualitatif, Ancaman Metodolog, Presentasi dan Publikasi Hasil Penelitian Untuk Mahasiswa dan peneliti Pemula Bidang Ilmu-Ilmu Sosial,Pendidikan dan Humaniora. Bandung : Pustaka Setia.

Gitosudarmo dan Sudita. 2000. Perilaku Organisasi. Yogjakarta: BPFE.

Gulo, W. 2010. Metodologi Penelitian. Jakarta : PT. Gramedia Widiasarana Indonesia.

Iman, Indra dan Siswandi. 2009. Aplikasi Manajemen Perusahaan, Analisis Kasus dan Pemecahannya. Jakarta : Mitra Wacana Media.

Labolo, Muhadam. 2013. Memahami Ilmu Pemerintahan, Suatu Kajian, Teori, Konsep dan Pengembangannya. Jakarta : PT. RajaGrafindo.

Manullang, M. 2009. Dasar-Dasar Manajemen. Yogyakarta: Gajah Mada University Press.

Mahsun, Mohamad. 2016. Pengukuran Kinerja Sektor Publik. Yogyakarta : BPFE

Mukarom, Zaenal dkk. 2015. Manajemen Pelayanan Publik. Bandung : Pustaka Setia.

Moleong, L.J. 2002. Metodologi Penelitian Kualitatif. Bandung: PT. R

Rasyid, Ryaas, 2002. Makna Pemerintahan, Tinjauan dari Segi Etika dan Kepemimpinan. Jakarta : PT. Yarsif Watampone.

Rusdiana dkk. 2014. Sistem Informasi Manajemen. Bandung : Pustaka Setia.

Syafii, Inu Kencana. 2011.Manajemen Pemerintahan. Bandung : Pustaka Reka Cipta.

Silalahi, Ulbert. 2002. Studi Tentang Ilmu Administrasi, Konsep, Teori dan Dimensi. Bandung : Sinar Baru Algensindo.

Siagian, S.P. 2015. Manajemen Sumber Daya Manusia. Jakarta: Bumi Aksara.

Siswandi dan Indra Iman. 2009. Aplikasi Manajemen Perusahaan Analisis Kasus dan pemecahannya. Jakarta : Mitra Wacana Media.

Sugiyono. 2017. Metode Penelitian, Kuantitatif, Kualitatif dan $R$ dan D. Bandung : Afabeta

\section{Peraturan Perundangan:}

Permenpan dan RB Nomor 35 Tahun 2012 Tentang Pedoman Penyusunan SOP Administrasi Pemerintahan.

Peraturan Pemerintah Nomor 43 Tahun 2014 tentang Peraturan Pelaksanaan UndangUndang Nomor 6 Tahun 2014 tentang Desa

Undang-Undang Nomor 23 Tahun 2014 Tentang Pemerintah Daerah 